\title{
Evaluation of Biostimulants to Control Guignardia Leaf Blotch (Guignardia aescult) of Horsechestnut and Black Spot (Diplocarpon rosae) of Roses
}

\author{
Jonathan M. Banks and Glynn C. Percival
}

\begin{abstract}
Biostimulants are classified as materials that are neither a fertilizer nor a pesticide, but when applied to a plant will enhance their health, growth, and protection. Manufacturers claim biostimulants have underexploited potential in providing protectant properties to plants against pathogen attack. This study evaluated the efficacy of seven commercially available biostimulants against the foliar pathogens Guignardia aesculi, leaf blotch of horsechestnut (Aesculus hippocastanum L.) and Diplocarpon rosae black spot of roses (Rosa "Pretty Polly"). None of the biostimulant products tested in this investigation achieved a sufficient degree of pathogen control to warrant replacement of or supplementation with conventional synthetic fungicides.

Key Words. Aesculus hippocastanum L.; Bio Control; Biostimulant; Diplocarpon rosae; Guignardia aesculi; Integrated Pest Management; Plant Health Care; Pathogen Suppression.
\end{abstract}

Foliar pathogens such as Guignardia leaf blotch (G. aesculi) of horsechestnut (Aesculus spp.) and black spot (Diplocarpon rosae) of roses (Rosa spp.) can result in serious economic losses for growers and vendors of ornamental plants as heavy infections can distract from plant aesthetic values (Marchant et al. 1998; Pastirčáková et al. 2009). New techniques of pathogen control are warranted due to the decreasing number of synthetic chemical controls coupled with greater plant pathogen insensitivity to conventional fungicides and public demands to reduce pesticide use, stimulated by greater awareness of environmental and health issues (Percival et al. 2009). Products referred to as biostimulants may be of future interest to those involved in the organic management of plant pathogens (Whipps 2001). Biostimulant formulations include compounds, such as acrylamide, amino acids, bacteria, carbohydrates, endo- and ectomycorrhizal fungi, humic acids, marine algae, wing of bat, nitrogen-fixing bacteria, plant hormones, sea kelp, vitamins, yucca extracts, and other substances that vary according to the manufacturer (Ferrini and Nicese 2002; Percival 2010). Manufacturers claim biostimulants, generally, conform to two modes of action: $i$ ) Activating a plant immune response, commonly known as systemic induced resistance (SIR); ii) Acting as fertilizers, despite the fact that their constituents differ from typical N:P:K fertilizers; therefore, their primary role is not direct nutrition (Thomson 2004; Percival 2010) but may be involved in promoting beneficial physiological processes or mycorrhizal associations known to be involved in plant defense (Azcon-Aguilar et al. 2002). Biostimulants may also be less susceptible to fungicidal insensitivity (Tronsmo 1991) and because of their natural constituents are considered less toxic to the environment and humans.
Previous research has shown applications of SIR products alone can result in resistance-induced yield increases of up to $367 \%$ (Burr et al. 1978), while applications of biostimulants exhibiting SIR activity reduced rooting and cut fungicide applications to nearly zero (Thompson 2004). Consequently, this study was undertaken to determine the effectiveness of seven different biostimulant products against Guignardia leaf blotch of horsechestnut, caused by G. aesculi and black spot of roses, caused by Diplocarpon rosae.

\section{MATERIALS AND METHODS}

Pot experiments using four-year-old stock of Rosa "Pretty Polly" (susceptible to black spot) and Aesculus hippocastanum L. (susceptible to Guignardia leaf blotch) were used. Twelve months prior to experiments, plants were potted into $5 \mathrm{~L}$ plastic pots filled with soil (loamy texture, $24 \%$ clay, $45 \%$ silt, $31 \%$ sand, $3.1 \%$ organic carbon, $\mathrm{pH} 6.2$ ), supplemented with the controlled release nitrogen-based N:P:K (29:7:9) fertilizer Bartlett BOOST (The Doggett Corporation, Lebanon, New Jersey, U.S.) at a rate of $1 \mathrm{~g} / \mathrm{kg}$ soil. Following potting, plants remained outdoors subject to natural environmental conditions and were watered as required. The experimental design used was a completely randomized block design in which pots were re-randomized on a weekly basis. Eight plants per treatment were spaced at $0.5 \mathrm{~m}$ to prevent competition for light. Plants were sprayed until runoff four times during the growing season (May 3, June 4, July 5, and August 4 , 2009) with a range of commercially available biostimulant products (Table 1). The lowest concentration used (Table 2) was based on the manufacturer's recommended rate of application. In addition, a double strength concentration of each product was also evaluated. A comparative evaluation of the fungicide Systhane (i.e., myclobutanil), commercially used for leaf blotch and 
black spot control, was conducted. Increases in horsechestnut and rose resistance were assessed by recording foliar pathogen severity on a 1-6 scale from ten randomly selected leaves per plant: $1=$ No pathogen attack observed; $2=$ less than $5 \%$ of leaf area affected with leaf blotch/black spot; $3=5 \%-20 \%$ of leaf area affected with leaf blotch/black spot plus some yellowing; $4=21 \%-50 \%$ of leaf area affected with leaf blotch/black spot and significant leaf yellowing; $5=51 \%-80 \%$ of leaf area affected with leaf blotch/ black spot, severe leaf yellowing; $6=81 \%-100 \%$ of leaf area infected with leaf blotch/black spot with complete leaf yellowing.

\section{RESULTS}

Irrespective of pathogen or concentration applied, none of the biostimulants used in this investigation provided a significant degree of Guignardia leaf blotch or black spot control compared to water-treated controls (Table 2). In the case of black spot and Guignardia leaf blotch, pathogen severity was reduced by $8.1 \%$ (Superthrive $0.5 \mathrm{ml}$ per liter) and $11.9 \%$ (Fulcrum CRV $20 \mathrm{ml}$ per liter) respectively. However, in some cases, biostimulant applications increased the severity of blackspot and Guignardia leaf blotch by $6.1 \%$ (Fulcrum $10 \mathrm{ml}$ per liter and $7.1 \%$ (Crop Set $20 \mathrm{ml}$ per liter) respectively (Table 2). Only the synthetic fungicide Systhane (myclobutanil), irrespective of concentration applied, provided a significant degree of pathogen control. In this instance, pathogen severity was reduced $66.7 \%-71.4 \%$ for black spot and $73.4 \%-79.6 \%$ for Guignardia leaf blotch (Table 2).

\section{DISCUSSION}

None of the biostimulants tested in this investigation achieved a sufficient degree of pathogen control to warrant replacement of a conventional synthetic fungicide. Therefore, despite the claims of some manufacturers, results of this study did not identify any reason to advocate the use of the biostimulants tested for plant protection purposes. Few independent peer-reviewed publications exist that have evaluated biostimulants for their plant protectant properties. The plant hormone/vitamin complex Superthrive, failed to inhibit germination of apple scab conidia, formation of appressoria, or reduce leaf scab severity compared to water-treated controls in a detached leaf bioassay under laboratory conditions; the conclusion was that this product had limited potential as a scab protectant compound (Percival 2010). Reasons for this lack of pathogen control efficacy can be suggested by reference to the use of biostimulants for other purposes. For example, biostimulants have been advocated as a means to enhance transplant survival of trees and improve crop yield and quality; however, similar to the results of this study, little influence of biostimulants on these parameters was recorded (Kelting et al. 1997; Thalheimer and Paoli 2001). Contradictory to this, Thomp-

Table 1. Selected biostimulants applied to horsechestnut (Aesculus hippocastanum) and Rosa "Pretty Polly" to control Guignardia leaf blotch and black spot, respectively.

\begin{tabular}{lll}
\hline Product & Active ingredient & Supplier \\
\hline Maxicrop Original & Seaweed extract & Maxicrop (UK) Ltd, Corby, UK \\
Resistim & Betaine & Mandops UK Ltd, Eastleigh, Hampshire, UK \\
Bioplex & Seaweed + humic acid extract & United Agri Products Ltd, Alconbury Weston, UK \\
Fulcrum CRV & Molasses & Banks Cargill Agriculture Ltd, St Hughs, Lincoln, UK \\
Redicrop & Seaweed (cytokinin activity) & United Agri Products Ltd, Alconbury Weston, UK \\
Crop Set & Lactobacillus fermentation & United Agri Products Ltd, Alconbury Weston, UK \\
& product and B5 vitamins & \\
Superthrive & Vitimin B and Auxin (NAA) & \\
Systhane & Myclobutanil (triazole) & Bartlett Tree Research Laboratory, Charlotte, NC \\
\hline
\end{tabular}

Table 2. Foliar pathogen severity rating on foliar tissue of horsechestnut (Aesculus hippocastanum) and Rosa "Pretty Polly."

\begin{tabular}{llll}
\hline Treatment & $\begin{array}{l}\text { Concentration } \\
\text { per liter }\end{array}$ & $\begin{array}{l}\text { Horsechestnut leaf } \\
\text { blotch severity rating }\end{array}$ & $\begin{array}{l}\text { Black spot } \\
\text { severity rating }\end{array}$ \\
\hline Water (control) & - & $4.9 \pm 0.56 \mathrm{a}$ & $4.2 \pm 0.30 \mathrm{a}$ \\
Maxicrop Original & $10 \mathrm{ml}$ & $4.7 \pm 0.54 \mathrm{a}$ & $4.3 \pm 0.33 \mathrm{a}$ \\
Maxicrop Original & $20 \mathrm{ml}$ & $5.1 \pm 0.58 \mathrm{a}$ & $4.0 \pm 0.29 \mathrm{a}$ \\
Resistim & $10 \mathrm{ml}$ & $4.8 \pm 0.46 \mathrm{a}$ & $3.8 \pm 0.31 \mathrm{a}$ \\
Resistim & $20 \mathrm{ml}$ & $5.2 \pm 0.53 \mathrm{a}$ & $4.2 \pm 0.32 \mathrm{a}$ \\
Bioplex & $10 \mathrm{ml}$ & $4.9 \pm 0.52 \mathrm{a}$ & $4.0 \pm 0.33 \mathrm{a}$ \\
Bioplex & $20 \mathrm{ml}$ & $4.7 \pm 0.47 \mathrm{a}$ & $3.7 \pm 0.31 \mathrm{a}$ \\
Fulcrum CRV & $10 \mathrm{ml}$ & $5.2 \pm 0.61 \mathrm{a}$ & $3.7 \pm 0.25 \mathrm{a}$ \\
Fulcrum CRV & $20 \mathrm{ml}$ & $4.8 \pm 0.50 \mathrm{a}$ & $4.4 \pm 0.33 \mathrm{a}$ \\
Redicrop & $10 \mathrm{ml}$ & $5.0 \pm 0.56 \mathrm{a}$ & $4.3 \pm 0.37 \mathrm{a}$ \\
Redicrop & $20 \mathrm{ml}$ & $4.8 \pm 0.55 \mathrm{a}$ & $4.5 \pm 0.34 \mathrm{a}$ \\
Crop Set & $10 \mathrm{ml}$ & $5.0 \pm 0.58 \mathrm{a}$ & $4.1 \pm 0.38 \mathrm{a}$ \\
Crop Set & $20 \mathrm{ml}$ & $4.6 \pm 0.60 \mathrm{a}$ & $4.0 \pm 0.29 \mathrm{a}$ \\
Superthrive & $0.25 \mathrm{ml}$ & $4.5 \pm 0.40 \mathrm{ab}$ & $4.2 \pm 0.31 \mathrm{a}$ \\
Superthrive & $0.50 \mathrm{ml}$ & $4.2 \pm 0.33 \mathrm{ab}$ & $1.4 \pm 0.04 \mathrm{~b}$ \\
Systhane & $0.3 \mathrm{ml}$ & $1.3 \pm 0.18 \mathrm{c}$ & $1.2 \pm 0.03 \mathrm{~b}$ \\
Systhane & $0.6 \mathrm{ml}$ & $1.0 \pm 0.14 \mathrm{c}$ & \\
\hline
\end{tabular}

Note: $1=$ No pathogen attack observed; $2=$ less than $5 \%$ of leaf area affected; $3=5 \%-20 \%$ of leaf area affected with some chlorosis; $4=21 \%-50 \%$ of leaf area affected, significant leaf chlorosis; $5=51 \%-80 \%$ of leaf area leaves affected, severe leaf chlorosis; $6=81 \%-100 \%$ of leaf area with complete leaf chlorosis. All values mean of six plants. Values followed by the same letter are not statistically significant $(P \leq 0.05)$ according to LSD. 
son (2004) and Sahain et al. (2007) demonstrated positive growth effects on plants following application of biostimulants. Reasons for these differences between authors were suggested by Barnes and Percival (2006), who identified that effects on growth can vary widely between tree species possibly as a result of $i$ ) the differing active ingredient used in the formulation of a biostimulant, and ii) the concentration applied. They concluded that this would be disadvantageous to the tree care industry where products with universal applicability for a wide range of species are required. Possibly such a response exists with respect to disease control (i.e., biostmulants proved non-effective in this instance against Guignardia leaf blotch and black spot of roses, but may prove effective against other diseases not tested in this investigation). Likewise, many biostimulants are now marketed in combination with a range of biological propagules, such as mycorrhizae and/ or growth promoting bacteria. However, the viability of many of these propagules can be a highly influential factor in affecting the degree of disease tolerance achieved (Corkidi et al. 2004). For example, out of ten products tested by Corkidi et al. (2004), mycorrhizal colonization varied from $0 \%$ to $50 \%$ and only one of the products promoted greater mycorrhizal colonization in a soil-based medium. Similar results (i.e., lack of efficacy) were recorded by Poincelot (1993), who evaluated the systemic inducing properties claim of biostimulants as a means of disease control. Consequently with the influx of biostimulants released into the amenity market, evaluating all of them independently is a time consuming and labor-intensive process. Results of this study indicate that where independent scientific data are not available to support the pathogen control claims of the manufacturer, then using an unevaluated biostimulant for this purpose is not recommended.

Acknowledgments. The authors are grateful for funding in part from the TREE FUND (Hyland Johns Grant).

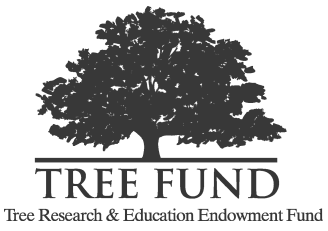

\section{LITERATURE CITED}

Azcon-Aguilar, C., M.C. Jaizme-Vega, and C. Calvet. 2002. The Contribution of Arbuscular Mycorrhizal Fungi to the Control of Soil-Borne Plant Pathogens. p. 187-197. In: G. Gianinazzi, H. Schuepp, J.M. Barea, and K. Haselwandter (Eds.). Mycorrhizal Technology in Agriculture: From Genes to Bioproducts. Birkhauser Verlag, Switzerland.

Barnes, S., and G.C. Percival. 2006. Influence of Biostimulants and Water-Retaining Polymer Root Dips on Survival and Growth of Newly Transplanted Bare-Rooted Silver Birch and Rowan. Journal of Environmental Horticulture 24(3):173-179.

Burr, T. J., M.N. Schroth, and T. Suslow. 1978. Increased potato yields by treatment of seedpieces with specific strains of Pseudomonas fluorescens and P. putida. Phytopathology 68:1377-1383.

Corkidi, L., E.B. Allen, D. Merhaut, M.F. Allen, J. Downer, J. Bohn, and M. Evans. 2004. Assessing the Infectivity of Commercial Mycorrhizal Inoculants in Plant Nursery Conditions. Journal of Environmental Horticulture 22(3):149-154.

Ferrini, F., and F.P. Nicese. 2002. Response of English oak (Quercus robour $\mathrm{L}$.) trees to biostimulants application in the urban environment. Journal of Arboriculture 28(2):70-75.

Kelting, M., J.R. Harris, J. Fanelli, B. Appleton, and A. Niemiea. 1997. Humate-based biostimulants do not consistently increase growth of container-grown Turkish hazelnut. Journal of Environmental Horticulture 15(4):197-199.

Marchant, R., M.R. Davey, J.A. Lucas, C.J. Lamb, R.A. Dixon, and J.B. Power. 1998. Expression of a chitinase tansgene in rose (Rosa hybrid L.) reduces development of black spot disease (Diplocarpon rosae Wolf). Molecular Breeding 4:187-194.

Pastirčáková, K., M. Pastirčák, F. Celar, and H. Shin. 2009. Guignardia aesculi on species of Aesculus: New records from Europe and Asia. Mycotaxon 108:287-296.

Percival, G.C. 2010. Effects of systemic inducing resistance and biostimulant materials on apple scab using a detached leaf bioassay. Arboriculture \& Urban Forestry 36(1):41-46.

Percival, G.C., K. Noviss, and I Haynes. 2009. Field evaluation of systemic inducing resistance chemicals at different growth stages for the control of apple (Venturia inaequalis) and pear (V. pirina) scab. Crop Protection 28:629-633.

Poincelot, R.P. 1993. The use of a commercial organic biostimulant for bedding plant production. Journal of Sustainable Agriculture 3(2):99-110.

Sahain, M.F.M., E.Z.A. El Motty, M.H. El- Shiekh, and L.F. Hagagg. 2007. Effect of some biostimulant on growth and fruiting of Anna apple trees in newly reclaimed areas. Research Journal of Agriculture and Biological Science 3(5):422-429.

Thalheimer, M., and N. Paoli. 2001. Effectiveness of Various Leaf-Applied Biostimulants on Productivity and Fruit Quality of Apple. International Symposium on Foliar Nutrition of Perennial Fruit Plants. 594. ISHS Acta Horticulturae.

Thompson, B.E. 2004. Five years of Irish Trials on Biostimulants - The Conversion of a Skeptic. USDA Forest Service Proceedings. RMRS-P-33.

Tronsmo, A. 1991. Biological and integrated controls of Botrytis cinerea on apple with Trichoderma harzianum. Biological Control 1:59-62.

Whipps, J.M. 2001. Microbial interactions and biocontrol in the rhizosphere. Journal of Experimental Botany 52:487-511. 
Jonathan M. Banks (corresponding author)

Bartlett Tree Research Laboratory

John Harborne Building, Whiteknights

University of Reading, Reading

Berkshire, RG6 6AS, UK

jbanks@bartlettuk.com

Glynn C. Percival

Bartlett Tree Research Laboratory

John Harborne Building, Whiteknights

University of Reading, Reading

Berkshire, RG6 6AS, UK

gpercival@bartlettuk.com

Résumé. Les bio-stimulants sont classés comme produits qui ne sont ni des fertilisants ni des pesticides, mais qui, lorsque appliqués aux végétaux, vont accroître leur santé, leur croissance et leur protection. Les manufacturiers clament que les bio-stimulants ont un potentiel inexploité en regard de leurs propriétés protectrices pour les plantes contre les attaques par les maladies pathogènes. Cette étude évalue l'efficacité de sept bio-stimulants commerciaux disponibles contre les maladies foliaires sur le marronnier d'Inde (Aesculus hippocastanum L.) que sont la rouille des feuilles du marronnier (Guignardia aesculi) et la tache noire des rosiers (Diplocarpon rosae). Aucun des bio-stimulants testés dans cette étude n'a permis d'atteindre un degré suffisant de contrôle de ces maladies afin de justifier le remplacement ou leur utilisation conjointe avec des fongicides synthétiques.

Zusammenfassung. Biostimulantien sind als Material klassifiziert, das weder ein Dünger noch ein Pestizid ist, aber bei Anwendung an einer Pflanze Auswirkungen auf die Gesundheit, Wachstum und Schutz hat. Die Hersteller behaupten, dass Biostimulantien ein unerforschtes Potential für den Schutz von Pflanzen gegen Attacken von Pathogenen bieten. Diese Studie bewertet die Effektivität von sieben kommerziell erhältlichen Biostimulantien gegen den Blattpathogen Guignardia aesculi, Blattfleckenkrankheit bei Rosskastanien (Aesculus hippocastanum L.) und Diplocarpon rosae Schwarze Flecken bei Rosen (Rosa "Pretty Polly"). Keins der in dieser Studie getesteten Biostimulantien erreichte einen ausreichenden Grad von Kontrolle, um einen Austausch oder Zugabe von konventionellen synthetischen Fungiziden zu rechtfertigen.

Resumen. Los bioestimulantes son clasificados como materiales que no son utilizados como fertilizantes ni pesticidas, pero cuando se aplican a las plantas relazan su salud, crecimiento y protección. Los fabricantes reclaman que los bioestimulantes tienen un potencial inexplorado por sus propiedades de protección de las plantas contra ataque de patógenos. Este estudio evaluó la eficacia de siete bioestimulantes comercialmente disponibles contra los patógenos foliares Guignardia aesculi, del castaño de Indias Aesculus hippocastanum L. y Diplocarpon rosae de las rosas (Rosa "Pretty Polly"). Ninguno de los productos probados en la investigación lograron un grado suficiente de control del patógeno para garantizar su remplazo o suplementación con fungicidas sintéticos convencionales. 